\title{
A glacier inventory for the western Nyainqentanglha Range and the Nam Co Basin, Tibet, and glacier changes 1976-2009
}

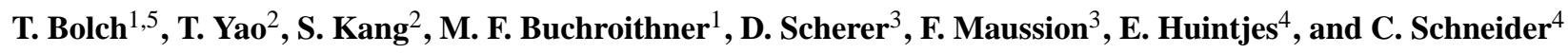 \\ ${ }^{1}$ Institut für Kartographie, Technische Universität Dresden, Dresden, Germany \\ ${ }^{2}$ Institute of Tibetan Plateau Research, Chinese Academy of Sciences, Beijing, China \\ ${ }^{3}$ Institut für Ökologie, Technische Universität Berlin, Berlin, Germany \\ ${ }^{4}$ Geographisches Institut, RWTH Aachen University, Aachen, Germany \\ ${ }^{5}$ Geographisches Institut, Universität Zürich, Zürich, Switzerland
}

Received: 5 March 2010 - Published in The Cryosphere Discuss.: 1 April 2010

Revised: 22 July 2010 - Accepted: 15 September 2010 - Published: 29 September 2010

\begin{abstract}
The western Nyainqentanglha Range is located in the south-eastern centre of the Tibetan Plateau. Its northwestern slopes drain into Lake Nam Co. The region is of special interest for glacio-climatological research as it is influenced by both the continental climate of Central Asia and the Indian Monsoon system, and situated at the transition zone between temperate and subcontinental glaciers. A glacier inventory for the whole mountain range was generated for the year around 2001 using automated remote sensing and GIS techniques based on Landsat ETM+ and SRTM3 DEM data. Glacier change analysis was based on data from Hexagon KH-9 and Landsat MSS (both 1976), Metric Camera (1984), and Landsat TM/ETM+ (1991, 2001, 2005, 2009). Manual adjustment was especially necessary for delineating the debris-covered glaciers and the glaciers on the panchromatic Hexagon data. In the years around 2001 the whole mountain range contained about 960 glaciers covering an area of $795.6 \pm 22.3 \mathrm{~km}^{2}$ while the ice in the drainage basin of Nam Co covered $198.1 \pm 5.6 \mathrm{~km}^{2}$. The median elevation of the glaciers was about $5800 \mathrm{~m}$ with the majority terminating around $5600 \mathrm{~m}$. Five glaciers with debris-covered tongues terminated lower than $5200 \mathrm{~m}$. The glacier area decreased by $-6.1 \pm 3 \%$ between 1976 and 2001 . This is less than reported in previous studies based on the 1970s topographic maps and Landsat data from 2000. Glaciers continued to shrink during the period 2001-2009. No advancing glaciers were detected. Detailed length measurements for five glaciers indicated a retreat of around $10 \mathrm{~m}$ per year
\end{abstract}

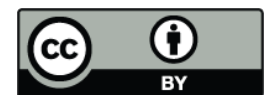

Correspondence to: $\mathrm{T}$. Bolch (tobias.bolch@geo.uzh.ch)
(1976-2009). Ice cover is higher south-east of the mountain ridge which reflects the windward direction to the monsoon. The temperature increase during the ablation period was probably the main driver of glacier wastage, but the complex glacier-climate interactions need further investigation.

\section{Introduction}

Often described as Asia's "water tower", the Tibetan Plateau (TiP) is the source area of many major rivers (e.g. Brahmaputra, Ganges, Huang He, Indus, Mekong, Yangtze). Glaciers on the TiP are characteristic elements of its natural environment and are contributing to its water resources (Immerzeel et al., 2010). TiP's climate showed a significant temperature increase since the mid 1950s latest (Liu and Chen, 2000; Frauenfeld et al., 2005; Kang et al., 2010), accompanied by an increase of the average precipitation (Zhao et al., 2004; Chen et al., 2009; Liu et al., 2009). The glaciers receded almost throughout the entire Tibetan Plateau during recent decades (Ding et al., 2006; Ye et al., 2006; Xiao et al., 2007; $\mathrm{Li}$ et al., 2008). Glacier shrinkage is also reported for the western Nyainqentanglha Range in particular (Kang et al., 2007a; Yao et al., 2007; Wu and Zhu 2008; Frauenfelder and Kääb, 2009). These studies are based on the comparison of satellite data with data from 1970s topographic maps. Frauenfelder and Kääb (2009) found uncertainties and location errors with this older data which is also available in the database of the GLIMS (Global Land Ice Measurements from Space) initiative ( $\mathrm{Li}, 2003)$. Recently started glacier mass balance measurements on Zhadang Glacier show negative mass balance values of about $-1000 \mathrm{~mm}$ w.e. per year

Published by Copernicus Publications on behalf of the European Geosciences Union. 


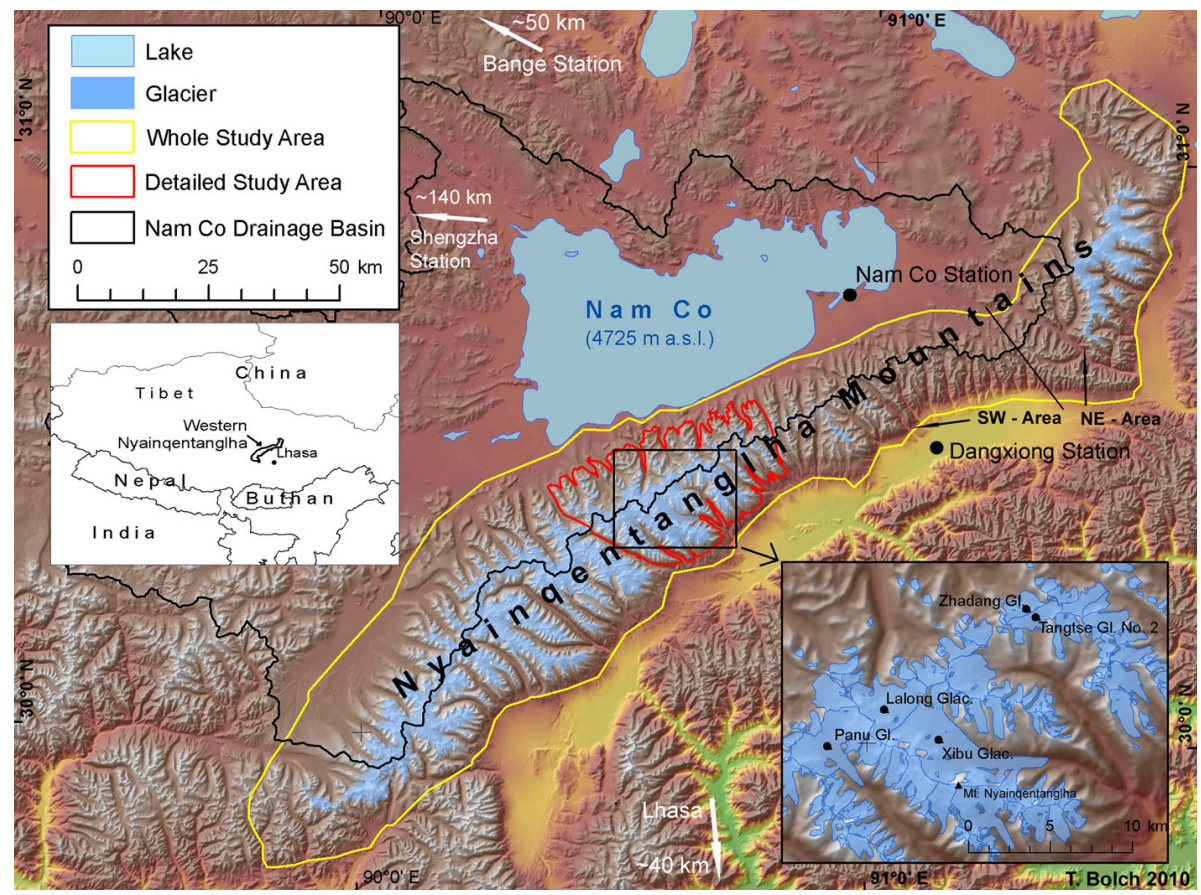

Fig. 1. Overview of the study area including the location of the climate stations (see Fig. 2) and the five glaciers studied in detail.

since 2005 except for a slightly positive balance in 2008 (Kang et al., 2009). Glacier wastage has not only caused an increase in river runoff from the plateau but also rising lake levels which are flooding pastures (Yao et al., 2007). There is a concern about an increasing threat from natural hazards such as landslides and glacial lake outburst floods (Ma et al., 2004), and decreasing water resources in the long run. These issues pose a need for evaluating the existing studies, and also for continuous glacier monitoring in this area.

Multi-temporal and multi-spectral satellite data are ideal to study and monitor glacier changes simultaneously over larger areas in remote mountainous terrain as they allow automated glacier mapping. A simple but robust method is the application of ratio images using one visible or near infrared and one short-wave infrared band (Bolch and Kamp, 2006; Paul et al., 2002). The earliest imagery suitable for automated mapping is available since the launch of Landsat TM in 1982. The availability of digital elevation models allows to split contiguous ice masses into their drainage basins, and to obtain characteristic topographic variables of the glaciers (e.g., minimum, maximum, median elevation, slope, aspect) automatically (Schiefer et al., 2008; Paul et al., 2009; Bolch et al., 2010). Declassified imagery from the US American intelligence satellite missions such as Corona KH-4, Corona $\mathrm{KH}-4 \mathrm{~B}$ and Hexagon KH-9, the first images of which are available from the early 1960s, is ideal to extend the analysis back in time (Bolch et al., 2008; Narama et al., 2010; Surazakov and Aizen, 2010).
To our knowledge there is no study published addressing all glaciers and their changes in the western Nyainqentanglha Range for more than two points in time. Therefore, the aims of this study are:

1. to generate a recent glacier inventory for the whole mountain range, and to provide information on the general glacier characteristics,

2. to evaluate the data accuracy from the 1970s based on the topographic maps using declassified imagery,

3. to analyse glacier changes from 1976 to 2009 ,

4. to analyse glacier variability in detail for a subset of glaciers,

5. to discuss possible climatic drivers for glacier changes.

\section{Study region, regional climate and glaciers}

The western Nyainqentanglha Range, situated in the southeastern centre of the TiP (Fig. 1), represents a SW-NE striking high-mountain range of approx. $230 \mathrm{~km}$ in length with heights between some 5000 and $7162 \mathrm{~m}$ (Mount Nyainqentanglha). The region is under the complex influence of both the continental climate of Central Asia and the Indian Monsoon system with prevailing western winds in the dry season and winds from eastern direction during the wet season (Kang et al., 2009). The main mountain ridge is both 

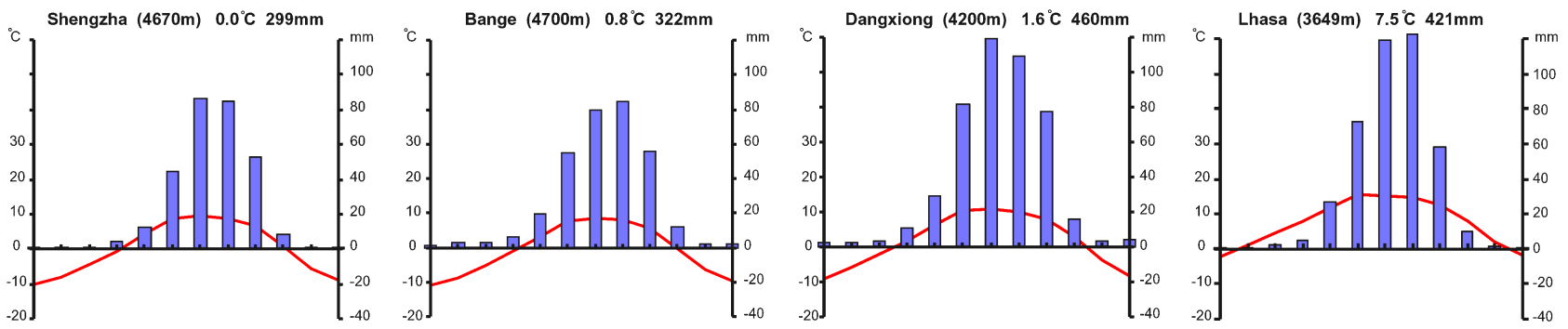

Fig. 2. Climate diagrams of Shengzha (also: Xainza), Bange (also: Bamgoin), Damxiong (also: Damxung), and Lhasa. The values are based on the period 1971-2000. Data source: National Climate Center of the Chinese Meteorological Administration; for the location of the climate stations see Fig. 1.

a water and climate divide. The SE exposed area is situated windward to the summer Monsoon and drains into the Yangbajain-Damxung Valley and subsequently into the Tsangpo-Brahmaputra River (cf. Yao, 2008). The northwestern slope drains into Lake Nam (Nam Co, $4725 \mathrm{~m}$, Fig. 1), Tibet's largest salt water lake with noticeable variations in size since the Last Glacial Maximum (Schütt et al., 2008), and also since 1970. From 1970 until 2006 the lake expanded its area by more than $50 \mathrm{~km}^{2}$ (Liu et al., 2010).

Relatively little is known about the regional mountain climate above $5000 \mathrm{~m}$ because of its high elevation and the lack of long-term observational data (Kang et al., 2010). However, assumptions can be made by analysing data from the nearest meteorological stations (e.g. Shengzha, Bange, Danxiong, Lhasa - Fig. 2, and Amdo, for the location see Fig. 1 and Miehe et al., 2001), and the recent installation of observational instruments on Zhadang Glacier and the nearby Nam Co station (You et al., 2007). Amdo, situated at $4820 \mathrm{~m}$, about $220 \mathrm{~km}$ in the NE, is currently the highest permanent climate station on the TiP (Liu et al., 2009). The mean annual air temperature at this station is $-3.0^{\circ} \mathrm{C}$. Mean annual precipitation at the meteorological station Danxiong situated east of the Nyainqentanglha Range is $460 \mathrm{~mm}$, and thus higher than the measured precipitation west of the mountain range (about $300 \mathrm{~mm}$ at the stations Shengzha and Bange) (Fig. 2). The annual precipitation measured at the Nam Co station ( $4725 \mathrm{~m}$ ) was $415 \mathrm{~mm}$ during the past three years (Zhang et al., 2008). Caidong and Sortenberg (2010) estimate a vertical increase in precipitation of $5 \%$ per $100 \mathrm{~m}$, and estimate annual precipitation values between $700 \mathrm{~mm}$ and more than $900 \mathrm{~mm}$ for Xibu Glacier situated close to Mt. Nyainqentanglha (see Fig. 1). A numerical modelling study also reports a SE-NW decrease of annual precipitation (Böhner, 2006), as the mountain range is a barrier for the summer monsoon. However, the climate is characterised by a strong seasonality in both temperature and precipitation. Only little precipitation is measured at the longterm meteorological stations, the Nam Co station and also estimated for Xibu Glacier (Caidong and Sortenberg, 2010) during the months November until March, while about $90 \%$ of mean annual precipitation is measured in the warm season from June to September (Fig. 2). Summer temperatures on Zhadang Glacier, at an elevation of about $5600 \mathrm{~m}$, observed by Kang et al. (2009) are ranging between 0.35 and $1{ }^{\circ} \mathrm{C}$. Following Sato (2001), summer mean temperatures are expected to be around $3{ }^{\circ} \mathrm{C}$ at the same elevation, illustrating the cooling effect of glaciated areas. Winter temperatures usually remain below $-15^{\circ} \mathrm{C}$ at this altitude.

Glaciers on the TiP are roughly classified into continental or subpolar and maritime or temperate glaciers (Huang, 1990). Continental type glaciers with little precipitation and cold ice are widely distributed from the central to the arid north-western plateau, while the maritime type with high monsoon precipitation and a temperate ice body is limited to the humid south-eastern region (Fujita et al., 1996; Fujita and Ageta, 2000). The snow-line elevation increases from about $4800 \mathrm{~m}$ in the humid south-eastern part to over $6200 \mathrm{~m}$ in the extremely continental north-eastern parts of the TiP (Shi et al., 1980). Measurements at Zhadang Glacier since 2005 indicate polythermal characteristics and an equilibrium line altitude (ELA) situated at about $5800 \mathrm{~m}$ (unpublished data). In the transitional zone between continental and maritime glaciers, the location of the western Nyainqentanglha Range, polythermal glaciers with both cold and temperate ice within the glacier body are common (Shi and Liu, 2000). These glaciers are located in a continental summerprecipitation climate with the maximum of annual accumulation and ablation occurring simultaneously in summer (Ageta and Fujita, 1996; Kang et al., 2009). Superimposed ice and internal accumulation play an important role in glacier mass balance as it prevents mass loss during the ablation season due to the retention of meltwater (Ageta and Fujita, 1996; Fujita et al., 2007). Additionally, monsoonal summer snowfall leads to increasing surface albedo and largely restrains ablation. These glaciers can therefore maintain their mass even under arid conditions with strong solar radiation (Fujita and Ageta, 2000; Kang et al., 2009). 


\section{Data and methods}

\subsection{Data}

The main source for the glacier inventory was Landsat TM/ETM+ scenes from different years (Table 1). The scenes were available from USGS (United States Geological Survey, http://glovis.usgs.gov/) and are orthorectified automatically by USGS using the SRTM3 DEM (level 1T). These scenes matched well our non-differential GPS-data (horizontal shift $<30 \mathrm{~m}$ ). No DGPS data were available for this study. We selected a Landsat ETM+ scene from 2001 as reference. For the ETM+ scenes almost no horizontal shift was observed, whereas the TM scenes had small systematic shifts of 15 to $20 \mathrm{~m}$. For the time $\sim 1990$, we found only one scene from 1991 at GLCF (Global Landcover Facility, www.landcover.org, correction level "geocover"; Tucker et al., 2004) with some seasonal snow cover.

Fortunately, the main area of interest around Mt. Nyainqentanglha and Zhadang Glacier is located in the centre of the ETM+ scenes, almost not affected by scanline errors present in ETM+ images since early summer 2003 ("SLCoff" scenes which have data gaps). Nevertheless, we had to use several SLC-off scenes for each year due to different snow conditions, cloud cover and the data gaps. A typical scene is shown in Fig. 3.

We utilized panchromatic Hexagon KH-9 data (resolution $\sim 8 \mathrm{~m}$, footprint $\sim 120$ by $240 \mathrm{~km}^{2}$ ) from 1976 to extend the coverage back in time and to evaluate the existing data from the Chinese Glacier Inventory (CGI; Li, 2003). Most glaciers were identifiable on the Hexagon scene, except of some smaller high-altitude glaciers, due to low contrast and snow cover. Hence, we used Landsat MSS data from the same year as a secondary source. Unfortunately, this scene also showed partly higher seasonal snow cover. Additional information was provided by Corona data from 1970 with a resolution of $4 \mathrm{~m}$, and by Space Shuttle Metric Camera (MC) imagery (Konecny et al., 1984) from the year 1984 with a resolution of $\sim 20 \mathrm{~m}$. Table 1 provides an overview of the utilized scenes.

We co-registered the scenes to the USGS scene from 2001, if the shift exceeded $15 \mathrm{~m}$. The Hexagon, Corona, and Metric Camera data had to be orthorectified, since no terrain correction had been applied to these data yet. The ETM+ images were pan-sharpened for visual checking and improvement. We orthorectified and co-registered the KH-9, MC and KH-4B imagery in a two-step approach using ERDAS Imagine software: The projective transformation was performed based on ground control points (GCPs) and the SRTM3DEM, followed by a spline adjustment. In total, we used 95 GCPs for the KH-9, 25 GCPs for KH-4, and 39 for the MC imagery.

Since no detailed DEM was available for the study area, we needed a suitable DEM not only for the orthorectification but also for the calculation of glacier parameters and the

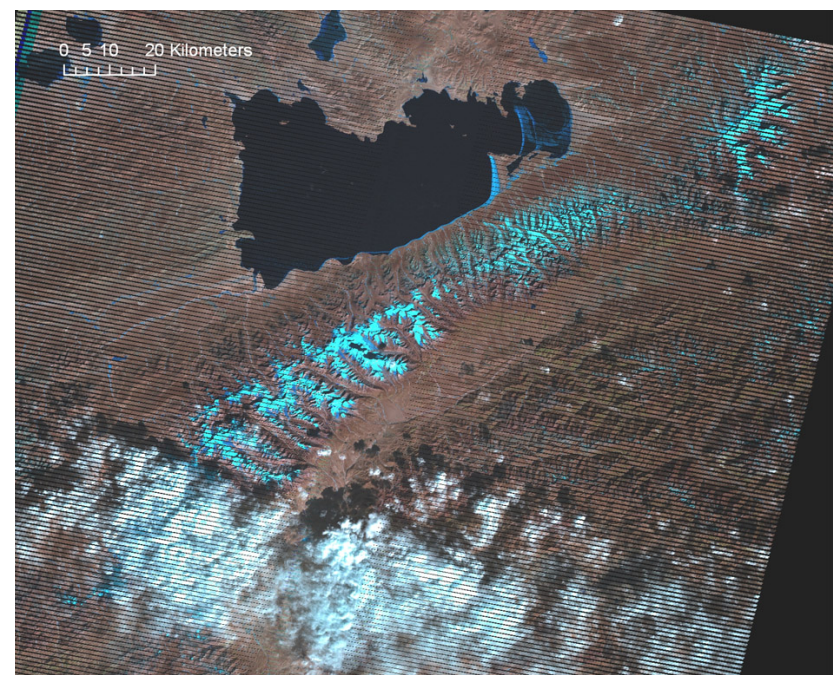

Fig. 3. Typical situation of a Landsat scene (ETM+ SLC-off from 18 January 2006): Part of the study area is suitable for glacier mapping, while seasonal snow hampers correct mapping in the NE region, and clouds covers the SW region. The region of highest interest in the center is not affected by scanline errors of the SLC scene.

separation of the glaciers into their drainage basins. Therefore, we downloaded and tested the void-filled SRTM3 data (90 $\mathrm{m}$ resolution) from the Consortium for Spatial Information - Consultative Group for International Agriculture Research (CSI - CGIAR), version 4 (http://srtm.csi.cgiar.org/) and the ASTER GDEM ( $30 \mathrm{~m}$ resolution). The registration of the ASTER GDEM turned out to be suitable as it matched the reference USGS Landsat scene with a deviation of less than $30 \mathrm{~m}$. The main disadvantage is that it contains artificial sinks and peaks, and does not accurately represent rock walls due to problems in image matching in steep or snow covered terrain (Kääb, 2001; Kamp et al., 2005; Toutin, 2008). The SRTM DEM, acquired in February 2000 is known to be of good height accuracy (Berry et al., 2007; Falorni et al., 2005), and has also the advantage that it is more accurate in areas of low optical contrast. The horizontal shift was less than one pixel to the USGS Landsat reference scene.

\subsection{Glacier identification}

We applied a semi-automated approach using the TM3/TM5 band ratio to produce glacier outlines using Landsat $\mathrm{TM} / \mathrm{ETM}+$ imagery. This method is most appropriate for glacier mapping in larger study areas following the recommendations for the compilation of glacier inventories (Paul et al., 2009; Racoviteanu et al., 2009) and previous experience (Bolch and Kamp, 2006; Bolch et al., 2010). In addition, a 3 by 3 median filter was applied which only marginally alters the glacier size but eliminates isolated pixels. These are usually misclassified pixels due to debris or boulders on the glacier (Paul et al., 2002). We visually checked glacier 
Table 1. Utilized space imagery.

\begin{tabular}{|c|c|c|c|c|c|c|c|}
\hline Date & $\begin{array}{l}\text { Satellite } \\
\text { and Sensor }\end{array}$ & Path/Row & $\begin{array}{l}\text { Spatial } \\
\text { Resolution }\end{array}$ & $\begin{array}{l}\text { Spectral } \\
\text { Bands }\end{array}$ & Source & $\begin{array}{l}\text { Suitability } \\
\text { of scene }\end{array}$ & Utilisation \\
\hline 21 Nov 1970 & $\begin{array}{l}\text { Corona } \\
\text { KH-4B }\end{array}$ & & $\begin{array}{l}\sim 4 \mathrm{~m}, \\
\text { stereo }\end{array}$ & $1 \mathrm{PAN}$ & $\mathrm{USGS}^{1}$ & & $\begin{array}{l}\text { Additional } \\
\text { information for } \\
\text { glacier identification }\end{array}$ \\
\hline 7 Jan 1976 & $\begin{array}{l}\text { Hexagon } \\
\text { KH-9 }\end{array}$ & & $\begin{array}{l}\sim 8 \mathrm{~m}, \\
\text { stereo }\end{array}$ & $1 \mathrm{PAN}$ & $\mathrm{USGS}^{1}$ & $\begin{array}{l}\text { Seasonal } \\
\text { snow on } \\
\text { NE part }\end{array}$ & $\begin{array}{l}\text { Glacier inventory } \\
\sim 1976 \text { for whole } \\
\text { study area }\end{array}$ \\
\hline 7 Dec 1976 & $\begin{array}{l}\text { Landsat } \\
\text { MSS }\end{array}$ & $\begin{array}{l}148 / 039 \\
148 / 039\end{array}$ & $79 \mathrm{~m}$ & 3 VIS, 1 NIR & $\mathrm{GLCF}^{2}$ & $\begin{array}{l}\text { Seasonal } \\
\text { snow on } \\
\text { NE part }\end{array}$ & $\begin{array}{l}\text { Glacier inventory } \\
\sim 1976 \text { for whole } \\
\text { study area }\end{array}$ \\
\hline 23 Nov 1984 & $\begin{array}{l}\text { Space } \\
\text { Shuttle } \\
\text { Metric } \\
\text { Camera }\end{array}$ & & $\begin{array}{l}\sim 16 \mathrm{~m}, \\
\text { stereo }\end{array}$ & $1 \mathrm{VIS}$ & $\mathrm{DLR}^{3}$ & $\begin{array}{l}\text { Seasonal } \\
\text { snow on } \\
\text { glaciers }\end{array}$ & $\begin{array}{l}\text { Additional } \\
\text { information for } \\
\text { selected glaciers }\end{array}$ \\
\hline 14 Sep 1991 & $\begin{array}{l}\text { Landsat } \\
\text { TM }\end{array}$ & $138 / 039$ & $30 / 120 \mathrm{~m}$ & $\begin{array}{l}3 \text { VIS, } 1 \text { NIR, } \\
2 \text { SWIR, } \\
1 \text { TIR }\end{array}$ & $\mathrm{GLCF}^{2}$ & $\begin{array}{l}\text { Seasonal } \\
\text { snow on } \\
\text { glaciers }\end{array}$ & $\begin{array}{l}\text { Additional } \\
\text { Information for } \\
\text { selected glaciers. }\end{array}$ \\
\hline 17 Nov 2000 & $\begin{array}{l}\text { Landsat } \\
\text { ETM+ }\end{array}$ & $138 / 039$ & $15 / 30 / 60 \mathrm{~m}$ & $\begin{array}{l}1 \text { PAN, } \\
3 \text { VIS, } 1 \text { NIR, } \\
2 \text { SWIR, } 1 \text { TIR }\end{array}$ & USGS $^{1}$ & $\begin{array}{l}\text { Seasonal } \\
\text { snow on } \\
\text { NE part }\end{array}$ & $\begin{array}{l}\text { Glacier inventory } \\
\sim 2001 \text {, additional } \\
\text { information }\end{array}$ \\
\hline 2 May 2001 & $\begin{array}{l}\text { Landsat } \\
\text { ETM+ }\end{array}$ & $138 / 039$ & $15 / 30 / 60 \mathrm{~m}$ & $\begin{array}{l}1 \text { PAN, } \\
3 \text { VIS, } 1 \text { NIR, } \\
2 \text { SWIR, } 1 \text { TIR }\end{array}$ & USGS $^{1}$ & $\begin{array}{l}\text { Seasonal } \\
\text { snow on } \\
\text { NE part }\end{array}$ & $\begin{array}{l}\text { Glacier inventory } \\
\sim 2001 \text {, additional } \\
\text { information }\end{array}$ \\
\hline 6 Dec 2001 & $\begin{array}{l}\text { Landsat } \\
\text { ETM+ }\end{array}$ & $138 / 039$ & $15 / 30 / 60 \mathrm{~m}$ & $\begin{array}{l}1 \text { PAN, } \\
3 \text { VIS, } 1 \text { NIR, } \\
2 \text { SWIR, } 1 \text { TIR }\end{array}$ & USGS $^{1}$ & $\begin{array}{l}\text { Seasonal } \\
\text { snow on } \\
\text { NE part }\end{array}$ & $\begin{array}{l}\text { Glacier inventory } \\
\sim 2001 \text {, whole } \\
\text { study area }\end{array}$ \\
\hline 20 Jan 2001 & $\begin{array}{l}\text { Terra } \\
\text { ASTER }\end{array}$ & & $\begin{array}{l}15 / 30 \mathrm{~m}, \\
\text { stereo }\end{array}$ & $\begin{array}{l}2 \text { VIS, NIR, } \\
\text { TIR }\end{array}$ & $\mathrm{USGS}^{1}$ & & $\begin{array}{l}\text { Glacier inventory } \\
\sim 2001 \text { additional } \\
\text { information }\end{array}$ \\
\hline 7 Oct 2005 & $\begin{array}{l}\text { Landsat } \\
\text { ETM+, } \\
\text { SLCoff }\end{array}$ & $138 / 039$ & $15 / 30 / 60 \mathrm{~m}$ & $\begin{array}{l}1 \text { PAN, } \\
3 \text { VIS, } 1 \text { NIR, } \\
2 \text { SWIR, } 1 \text { TIR }\end{array}$ & $\mathrm{USGS}^{1}$ & & $\begin{array}{l}\text { Additional } \\
\text { information for } \\
\text { selected glaciers }\end{array}$ \\
\hline 18 Jan 2006 & $\begin{array}{l}\text { Landsat } \\
\text { ETM+, } \\
\text { SLCoff }\end{array}$ & $138 / 039$ & $15 / 30 / 60 \mathrm{~m}$ & $\begin{array}{l}1 \text { PAN, } \\
3 \text { VIS, } 1 \text { NIR, } \\
2 \text { SWIR, } 1 \text { TIR }\end{array}$ & $\mathrm{USGS}^{1}$ & & $\begin{array}{l}\text { Additional } \\
\text { information for } \\
\text { selected glaciers }\end{array}$ \\
\hline 1 Aug 2007 & $\begin{array}{l}\text { Landsat } \\
\text { ETM+, } \\
\text { SLCoff }\end{array}$ & $138 / 038$ & $15 / 30 / 60 \mathrm{~m}$ & $\begin{array}{l}1 \text { PAN, } \\
3 \text { VIS, } 1 \text { NIR, } \\
2 \text { SWIR, } 1 \text { TIR }\end{array}$ & $\mathrm{USGS}^{1}$ & & $\begin{array}{l}\text { Glacier inventory } \\
\text { NE part }\end{array}$ \\
\hline 6 Jan 2008 & $\begin{array}{l}\text { Landsat } \\
\text { ETM+, } \\
\text { SLCoff }\end{array}$ & $138 / 039$ & $15 / 30 / 60 \mathrm{~m}$ & $\begin{array}{l}1 \text { PAN, } \\
3 \text { VIS, } 1 \text { NIR, } \\
2 \text { SWIR, } 1 \text { TIR }\end{array}$ & $\mathrm{USGS}^{1}$ & $\begin{array}{l}\text { some } \\
\text { seasonal snow }\end{array}$ & $\begin{array}{l}\text { Glacier inventory } \\
\sim 2009 \text { NE part and } \\
\text { detailed study area }\end{array}$ \\
\hline 19 Jun 2009 & $\begin{array}{l}\text { Landsat } \\
\text { ETM+, } \\
\text { SLCoff }\end{array}$ & $138 / 039$ & $15 / 30 / 60 \mathrm{~m}$ & $\begin{array}{l}1 \text { PAN, } \\
3 \text { VIS, } 1 \text { NIR, } \\
2 \text { SWIR, } 1 \text { TIR }\end{array}$ & $\mathrm{USGS}^{1}$ & Some clouds & $\begin{array}{l}\text { Glacier inventory } \\
\sim 2009 \text { NE part and } \\
\text { detailed study area }\end{array}$ \\
\hline $21 \mathrm{Jul} 2009$ & $\begin{array}{l}\text { Landsat } \\
\text { ETM+, } \\
\text { SLCoff }\end{array}$ & $138 / 039$ & $15 / 30 / 60 \mathrm{~m}$ & $\begin{array}{l}1 \text { PAN, } \\
3 \text { VIS, } 1 \text { NIR, } \\
2 \text { SWIR, } 1 \text { TIR }\end{array}$ & $\mathrm{USGS}^{1}$ & Some clouds & $\begin{array}{l}\text { Glacier inventory } \\
\sim 2009 \text { NE part and } \\
\text { detailed study area }\end{array}$ \\
\hline 15 Sep 2009 & $\begin{array}{l}\text { Landsat } \\
\text { TM }\end{array}$ & $138 / 039$ & $30 / 120 \mathrm{~m}$ & $\begin{array}{l}3 \text { VIS, } \\
1 \text { NIR, } 2 \text { SWIR, } \\
1 \text { TIR }\end{array}$ & USGS $^{1}$ & $\begin{array}{l}\text { Some } \\
\text { clouds }\end{array}$ & $\begin{array}{l}\text { Glacier inventory } \\
\sim 2009 \text { NE part and } \\
\text { detailed study area }\end{array}$ \\
\hline
\end{tabular}

${ }^{1}$ United States Geological Survey (www.glovis.usgs.gov), ${ }^{2}$ Global Landcover Facility (www.landcover.org), ${ }^{3}$ Deutsches Zentrum für Luft und Raumfahrt (www.dlr.de) 


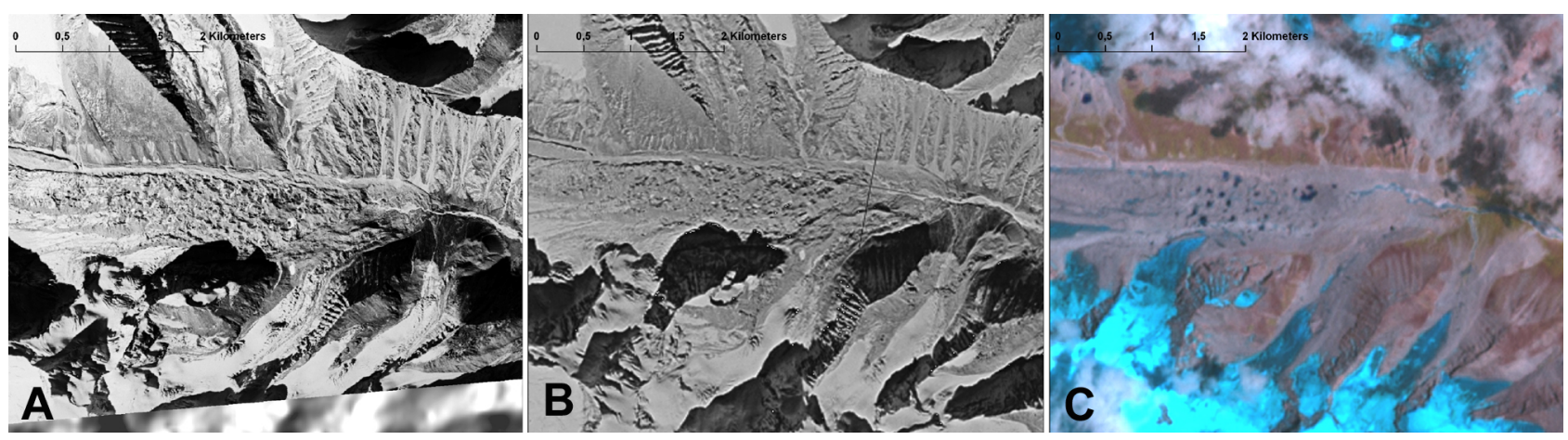

Fig. 4. Terminus of debris-covered Xibu Glacier; Corona, year 1970 (A), Hexagon, 1976 (B), Landsat ETM+, 5-4-3-pan, 2009 (C).

polygons derived from the ratio method for gross errors, and manually improved them where necessary. Debris-covered ice, proglacial lakes, seasonal snow and, for the SLC-off scenes, data gaps represented major sources of misclassified areas. The termini of some debris-covered glaciers were hardly identifiable by Landsat imagery. Here, we used the ETM+ pan-sharpened image to identify the most likely margin. The higher resolution Hexagon and Corona imagery (Fig. 4) helped in this process. Signs of movements, supraglacial ponds or creeks beginning at the end of the terminus are typical indicators which helped to determine the most likely position of the termini.

According to the recommendations to obtain a global glacier coverage for the time around the year 2000 (Paul et al., 2009), we generated an baseline inventory for the whole southern mountain range based on the Landsat ETM+ scene from the 6 December 2001 in the first step. In case of cast shadow and higher seasonal snow cover we used the other scenes from 2001 and 2000 as additional information. High seasonal snow hampered the correct mapping of the glaciers in the northern part. We had to use the three scenes from 2009 to map glaciers in this area due to clouds and the data gaps from the scan line error. The northernmost glaciers had to be mapped based on a 2007 scene from another row. Finally, full spatial coverage was obtained. We manually adjusted the 2001 outlines to the situation in 1976 based on the Hexagon and MSS data. No multi-temporal inventory could be generated for the north-eastern part of the mountain range (see Fig. 1) due to snow cover on both the Hexagon and the MSS data. The 2009 inventory for the detailed study area was generated semi-automatically as described above. The minimum size of mapped glaciers to be included in the inventory was set to $0.01 \mathrm{~km}^{2}$. However, the comparison of glacier areas was restricted to those larger $0.1 \mathrm{~km}^{2}$ as seasonal snow on at least one of the utilized scenes hampered the correct delineation, thus high errors would have been introduced. We could not find a single glacier that advanced between 1976 and 2001. Hence, we clipped all glaciers to the 1976 extend. The use of this mask ensured that the upper glacier boundary and the margins of the nunataks were kept constant, and no error was introduced due to varying seasonal snow cover or different ice divides.

\subsection{Glacier inventory and change analysis}

The contiguous ice masses were divided into their drainage basins in order to obtain a glacier inventory. We followed the automated approach presented by Bolch et al. (2010), and derived the basins based on hydrological analysis within a onekilometre-buffer around each glacier. The SRTM3 DEM was suitable to detect flow divides also on ice fields. The main drawback, however, was the location of some steep mountain crests. They differed sometimes by approximately one pixel $(90 \mathrm{~m})$ from the location in the satellite imagery. An additional error occurred when smaller glaciers, connected in parts of the accumulation area, are close to larger ones so that no basin was generated automatically. Hence, we manually improved the basins based on the satellite imagery. This method was superior to the fully manual method as many ice divides were calculated accurately by the automatic method.

An identification number was assigned to each glacier based on the 1976 extends. We treated all ice masses as a single glacier also in cases where glaciers separated from each other in order to allow subsequent change analysis. The following characteristic parameters were obtained for each glacier and the years 1976 and 2001 based on the SRTM3 DEM: hypsography, minimum, maximum and median elevation, mean slope, and aspect. The SRTM3 DEM matches well with the 2001 outlines. No DEM representing the 1976 conditions were available. Hence, slight biases especially with the hypsography of 1976 occur.

Five selected glaciers (Panu, Lalong, Xibu, Zhadang, and Tangtse Glacier No. 2, Fig. 1) were studied in detail. The selection is based on existing studies that could be used for comparison (Kang et al., 2007a). The glaciers are exposed to different aspects but are not representative for the entire mountain range due to their relatively large size. We manually adjusted the outlines for the additional years 1991 and 2005, and for Xibu and Lalong Glacier for the additional year 1984. High seasonal snow cover on the Metric Camera 

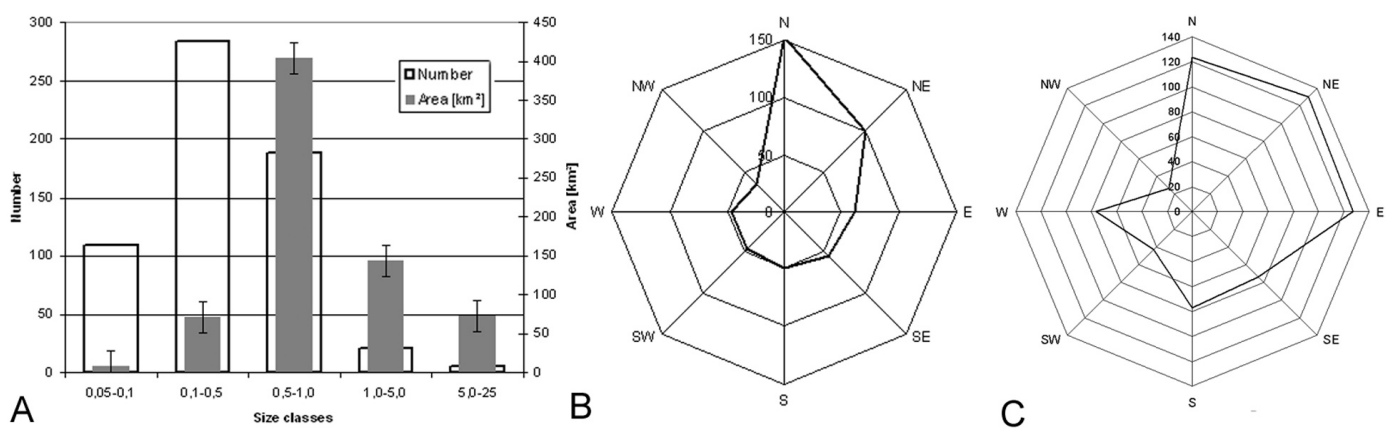

Fig. 5. Diagram showing the number and area covered for different size classes (A), aspect of the glaciers - (B): number, (C): area).

data hampered the correct delineation of the other glaciers for 1984.

\subsection{Error estimation}

The potential error of the multi-temporal analysis mainly arises from positional and mapping errors. Visual checks of (almost) stable landforms like mountain peaks or lateral moraines on the co-registered imagery resulted in a mean horizontal shift of one pixel or less for the TM scenes $(<30 \mathrm{~m})$, and less than half a pixel for the ETM+ scenes $(<15 \mathrm{~m})$. Some ETM+ scenes from the USGS matched perfectly. Co-registration error of the Hexagon image was higher due to the more complex image geometry. The error was about two pixels $(<20 \mathrm{~m})$ for the detailed study area, and could be up to four $(<40 \mathrm{~m})$ at the outer part of the imagery where fewer tie points (TPs) were collected. Uncertainty of glacier mapping depends on the resolution of the utilised imagery and the conditions at the time of the acquisition (especially seasonal snow). Under best conditions an accuracy of less than half a pixel can be achieved. We estimated the uncertainty by the buffer method suggested by Bolch et al. (2010) and Granshaw and Fountain (2006). We have chosen a buffer size of $10 \mathrm{~m}$ for the Hexagon image, and $7.5 \mathrm{~m}$ for the ETM+ images. This led into an uncertainty of the mapped glacier area of 3.5\% for the Hexagon imagery, and $2.8 \%$ for the ETM+ images on average. These uncertainties are within the range of previous accuracy estimates (Paul et al., 2002; Bolch and Kamp, 2006).

\section{Results}

\subsection{Glacier characteristics}

The whole mountain range contains almost 1000 glaciers according to our inventory. However, glacier counts are vague and depend on the purpose; e.g. contiguous ice masses can be counted as single entities, or can be subdivided into multiple glaciers as we did where parts of the ice masses cross ridges. Glaciers of the whole western Nyainqentanglha Range cover an area of about $800 \mathrm{~km}^{2}$, while slightly more than $100 \mathrm{~km}^{2}$
Table 2. Number and ice covered area of the study regions based on the glacier inventory. See Fig. 1 for the regions.

\begin{tabular}{lccl}
\hline Region & $\begin{array}{c}\text { Number of } \\
\text { glaciers }\end{array}$ & Area $\left(\mathrm{km}^{2}\right)$ & $\begin{array}{l}\text { Year of } \\
\text { utilized } \\
\text { images }\end{array}$ \\
\hline Whole Mountain range & 963 & $795.6 \pm 22.3$ & $\begin{array}{l}2001(\mathrm{SW}), \\
\text { 2007/2009 (NE) }\end{array}$ \\
NE section & 141 & $103.2 \pm 2.9$ & 2009 \\
SW section & 822 & $692.3 \pm 19.4$ & 2001 \\
Nam Co drainage basin & 305 & $198.1 \pm 5.6$ & 2001 \\
Detailed study area & 308 & $194.5 \pm 5.5$ & 2001 \\
\hline
\end{tabular}

are situated in the north-eastern section, which was not further investigated. Ice coverage of the detailed study area and of the Nam Co drainage basin is slightly less than $200 \mathrm{~km}^{2}$ each (Table 2). Glaciers draining into Nam Co are almost all situated at the north-western slope of the south-western part of the western Nyainqentanglha Range, except three small ones with an area of about $0.3 \mathrm{~km}^{2}$ which are situated in the north-eastern section, and five glaciers $\left(\sim 1.3 \mathrm{~km}^{2}\right)$ below mountain peaks not within the main range. The mean glacier size in the Nam Co drainage basin (year 2001) is about $0.64 \mathrm{~km}^{2}$, while the glaciers south east of the main ridge are on average about $0.88 \mathrm{~km}^{2}$ in size.

The highest number of glaciers can be found in the size class $0.1-0.5 \mathrm{~km}^{2}$, whereas glaciers between $0.5-1.0 \mathrm{~km}^{2}$ cover the largest area (Fig. 5a). Most glaciers are facing north while the east sector has a similar ice covered area as the northern sector (Fig. $5 b$ and c). Hence, the east facing glaciers are on average the largest. This is in line with the fact that the ice cover east (windward to the summer monsoon) of the main ridge of the Nyainqentanglha range is more than twice as large as the western part $\left(\sim 494 \mathrm{~km}^{2}\right.$ to $\left.\sim 196 \mathrm{~km}^{2}\right)$.

Median elevation of the glaciers, which is a suitable and widely used estimation for the long-term ELA based on topographic data (Braithwaite and Raper, 2010), is situated at around $5820 \mathrm{~m}$. The majority of the glaciers terminate 
Table 3. Characteristics of the glaciers investigated in detail based on the 2001 extents.

\begin{tabular}{|c|c|c|c|c|c|c|c|c|}
\hline Glacier & $\begin{array}{l}\text { GLIMS ID/WGI } \\
\text { ID* }\end{array}$ & $\begin{array}{r}\text { Area } \\
\left(\mathrm{km}^{2}\right)\end{array}$ & $\begin{array}{c}\text { Length } \\
(\mathrm{km})\end{array}$ & Aspect & $\begin{array}{l}\mathrm{H} \mathrm{med}^{1} \\
\text { (m a.s.l.) }\end{array}$ & $\begin{array}{l}\mathrm{H} \mathrm{min}^{2} \\
\text { (m a.s.l.) }\end{array}$ & $\begin{array}{l}\mathrm{H} \mathrm{max}^{3} \\
\text { (m a.s.l.) }\end{array}$ & $\begin{array}{l}\text { Debris- } \\
\text { covered } \\
\text { tongue }\end{array}$ \\
\hline Zhadang & $\begin{array}{l}\text { G090633E30476N/ } \\
\text { 5Z225D0003 }\end{array}$ & 2.48 & 2.7 & $\mathrm{NE}$ & 5710 & 5500 & 6095 & No \\
\hline $\begin{array}{l}\text { Tangse } \\
\text { No. } 2\end{array}$ & $\begin{array}{l}\text { G090647E30462N/ } \\
5 \mathrm{O} 270 \mathrm{C} 0086\end{array}$ & 2.96 & 2.1 & SW & 5785 & 5600 & 6080 & No \\
\hline Lalong & $\begin{array}{l}\text { G090540E30424N/ } \\
5 \mathrm{Z} 225 \mathrm{D} 0022\end{array}$ & 10.29 & 3.6 & NW & 5890 & 5340 & 6650 & $\begin{array}{l}\text { Few } \\
\text { medial } \\
\text { moraines }\end{array}$ \\
\hline Xibu & $\begin{array}{l}\text { G090601E30395N/ } \\
5 \mathrm{O} 270 \mathrm{C} 0065\end{array}$ & 23.35 & 9.3 & $\mathrm{E}$ & 5815 & 5160 & 7090 & Yes \\
\hline Panu & $\begin{array}{l}\text { G090521E30384N/ } \\
5 \mathrm{O} 270 \mathrm{C} 0044\end{array}$ & 12.88 & 5.3 & SE & 5850 & 5335 & 6365 & $\begin{array}{l}\text { Few } \\
\text { medial } \\
\text { moraines }\end{array}$ \\
\hline
\end{tabular}

* ID number of the GLIMS data base (Li 2003, www.glims.org) and the World Glacier Inventory (www.wgms.ch), ${ }^{1}$ median elevation, ${ }^{2}$ minimum elevation, ${ }^{3}$ maximum elevation

at around $5600 \mathrm{~m}$. Only five glaciers terminate lower than $5200 \mathrm{~m}$, with the lowest elevation at $5130 \mathrm{~m}$. These glaciers all have debris-covered tongues. We have identified 29 glaciers with significant debris cover. Overall area covered by debris was about $20 \mathrm{~km}^{2}(\sim 3 \%$ of the whole ice cover). Most of the debris-covered glaciers are situated in the outer south western part and around Mt. Nyainqentanglha below high and steep rock walls such as Xibu Glacier. These glaciers are typically large valley glaciers (average size about $4.4 \mathrm{~km}^{2}$ ). Characteristics of Xibu and the four other glaciers investigated in detail are shown in Table 3.

\subsection{Glacier shrinkage/recession}

Ice cover in the south-western study area diminished by about $-42 \mathrm{~km}^{2}(\sim-5.7 \%)$ in the period 1976-2001 (Table 4). Percentage loss and rate for Nam Co drainage basin and the detailed study area around Mt. Nyainqentanghla were in a similar range but slightly higher for the first, and lower for the latter. Shrinkage of the glaciers situated southeast of the main ridge was about $-29.5 \mathrm{~km}^{2}(\sim-5.5 \%)$. Glaciers with debris-covered tongues lost about $-4.5 \mathrm{~km}^{2}$ $(\sim-3.4 \%)$. The shrinkage rate for the period 2001-2009 was higher than for 1976-2001 but not statistically significant given the higher error term. However, visual checks and detailed analysis confirmed ongoing glacier shrinkage and retreat between 2001 and 2009 (Fig. 6 and Table 4). The overall number of glaciers remained almost unchanged. Disappearance of very few glaciers was compensated through disintegration of others. Disappeared glaciers were small and situated at relatively low altitudes.

Analysis of the relative area change against the initial glacier area indicated greater relative loss for smaller

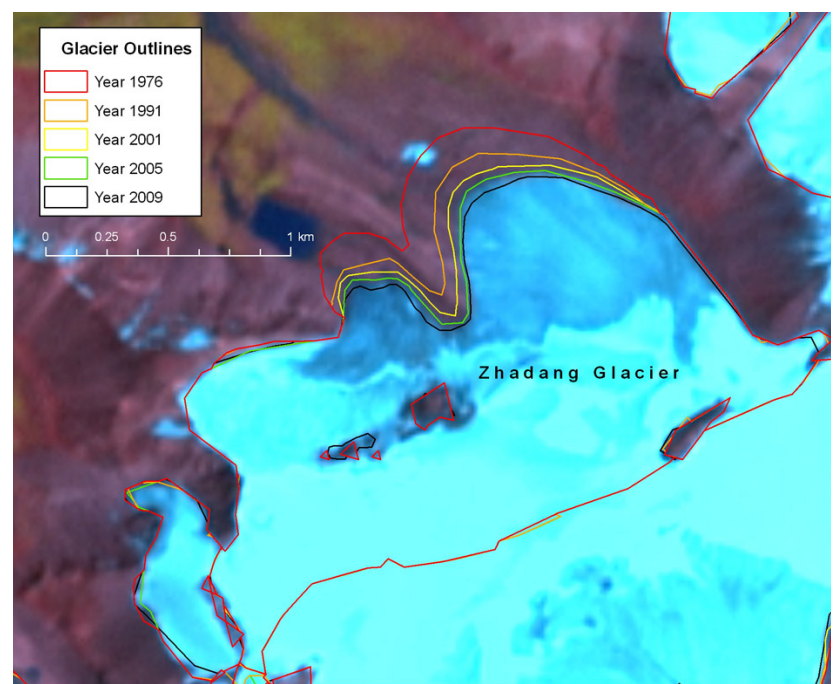

Fig. 6. Area changes of Zhadang Glacier (1976-2009).

glaciers. However, there was a large scatter, especially for smaller ones, and in all size classes there are glaciers, which did not shrink (Fig. 7a). Absolute area loss was higher for larger glaciers (Fig. 7c). Glaciers in the size classes $<0.5 \mathrm{~km}^{2}$ and $>5.0 \mathrm{~km}^{2}$ lost both almost $-7 \mathrm{~km}^{2}$ of ice, which is $\sim-11.4 \%$ of their initial glacier size for the first size class but only $\sim-3.3 \%$ for the latter. Glaciers with lower median elevation tended to lose relatively more area than higher elevation glaciers (Fig. 7b).

Analysis of the glacier hypsography showed that ice coverage above $6000 \mathrm{~m}$ remains almost unchanged while the highest absolute ice loss occured between 5500 and $5700 \mathrm{~m}$ 

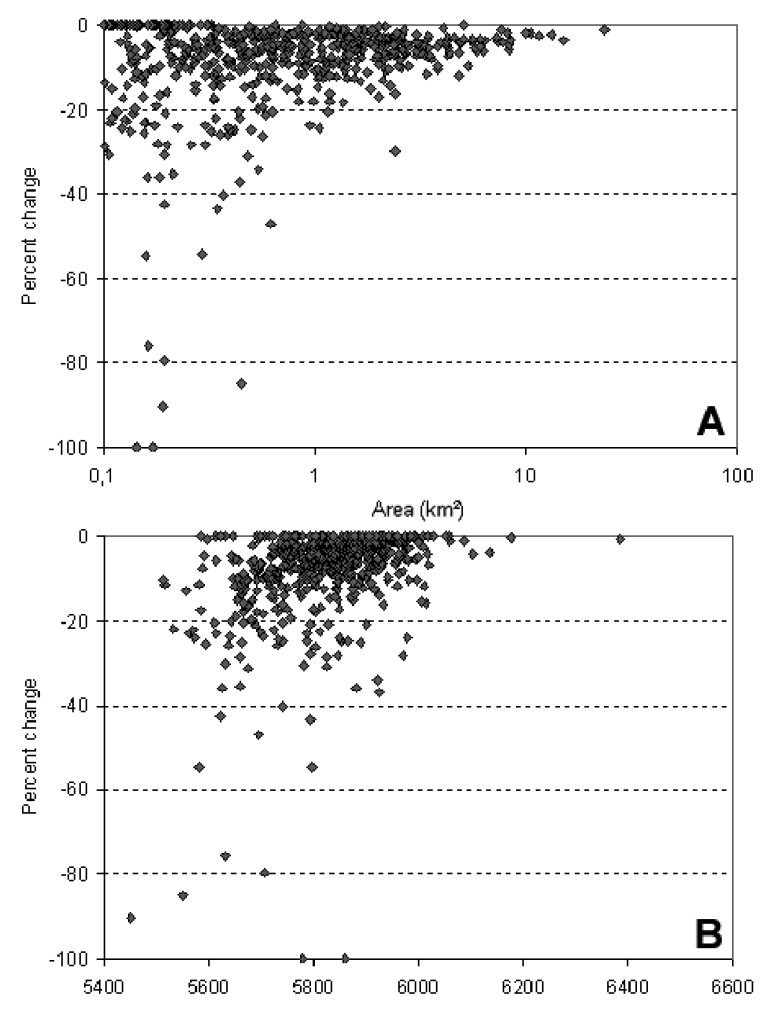

Median elevation (m a.s. I.)
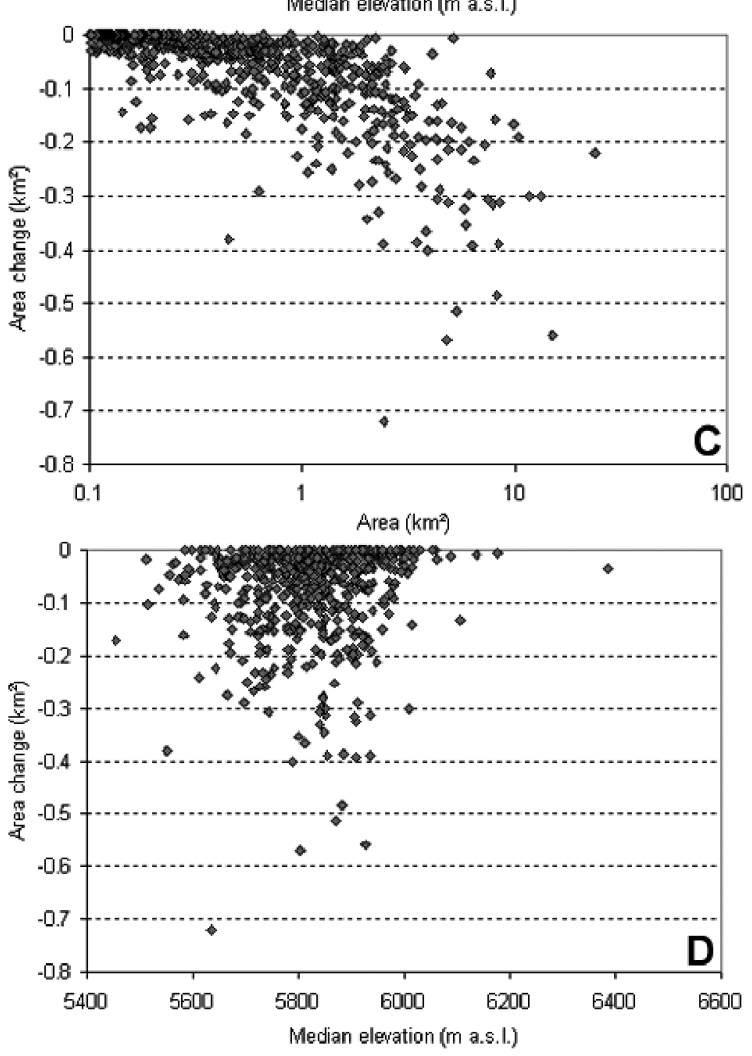

Fig. 7. Relative change in glacier area 1976-2001 versus initial glacier area (A) and median elevation (B), absolute change in glacier area 1976-2001 versus initial glacier area (C) and median elevation (D).

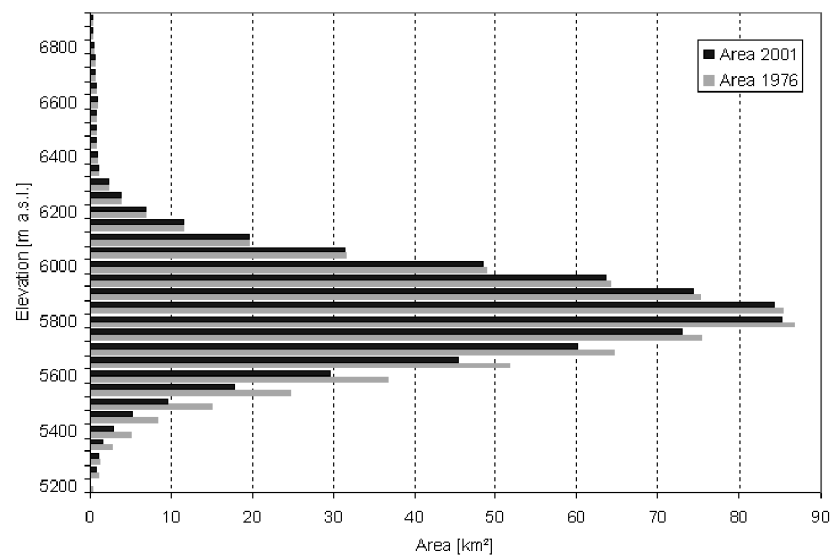

Fig. 8. Changes in glacier hypsometry 1976-2001; each bar represents an elevation interval of $50 \mathrm{~m}$.

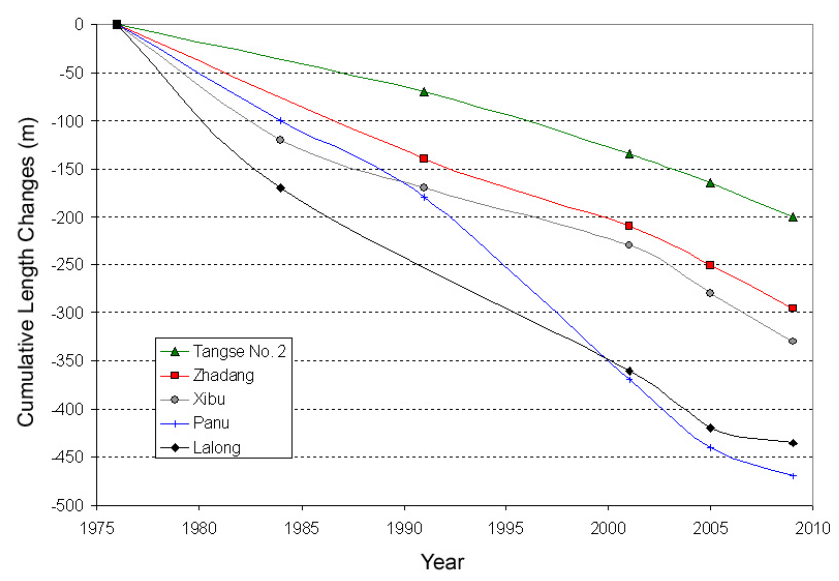

Fig. 9. Cumulative length change of the five glaciers studied in detail.

(Fig. 8). Median elevation increased by $9 \mathrm{~m}$ while the average minimum elevation of the glaciers rose about $15 \mathrm{~m}$ from 5671 to $5686 \mathrm{~m}$.

A detailed analysis of the five selected glaciers confirmed the above mentioned tendencies. All glaciers decreased continuously, both in area and length throughout all investigated periods (Table 5, Fig. 9). Minimum elevation increased on average about $30 \mathrm{~m}$ between 1976 and 2001 with the highest value $(75 \mathrm{~m})$ for Lalong Glacier. The tongue of this glacier terminates in a comparatively steep valley. The rate of area loss was significantly higher for three glaciers in the period 2001-2009 compared to 1976-2001, whereas the rate was similar for Panu Glacier, and an opposite tendency could be found for Lalong Glacier. Length changes showed similar characteristics. Absolute area loss varied between $-0.24 \mathrm{~km}^{2}$ (Tangtse Glacier No. 2, one of the smallest glaciers) and $-0.44 \mathrm{~km}^{2}$ (Xibu Glacier, the largest one) for 1976-2009, while percentage loss was highest for Zhadang Glacier $(-14.2 \%$, the smallest glacier studied), and lowest 
Table 4. Change in glacier area 1976-2001-2009.

\begin{tabular}{|c|c|c|c|c|c|c|c|c|c|c|c|c|}
\hline & \multicolumn{3}{|c|}{ Area $\left[\mathrm{km}^{2}\right]$} & \multicolumn{3}{|c|}{ 1976-2001 } & \multicolumn{3}{|c|}{ 2001-2009 } & \multicolumn{3}{|c|}{ 1976-2009 } \\
\hline & 1976 & 2001 & 2009 & $\begin{array}{l}\Delta a \\
{\left[\mathrm{~km}^{2}\right]}\end{array}$ & $\begin{array}{l}\Delta a \\
{[\%]}\end{array}$ & $\begin{array}{l}\Delta a / \mathrm{yr} \\
{[\%]}\end{array}$ & $\begin{array}{l}\Delta a \\
{\left[\mathrm{~km}^{2}\right]}\end{array}$ & $\begin{array}{l}\Delta a \\
{[\%]}\end{array}$ & $\begin{array}{l}\Delta a / \mathrm{yr} \\
{[\%]}\end{array}$ & $\begin{array}{l}\Delta a \\
{\left[\mathrm{~km}^{2}\right]}\end{array}$ & $\begin{array}{l}\Delta a \\
{[\%]}\end{array}$ & $\begin{array}{l}\Delta a / \mathrm{yr} \\
{[\%]}\end{array}$ \\
\hline $\begin{array}{l}\text { South- } \\
\text { Western } \\
\text { Region }\end{array}$ & $\begin{array}{l}734.1 \\
\pm \\
25.7\end{array}$ & $\begin{array}{l}692.4 \\
\pm \\
19.4\end{array}$ & n.a. & $\begin{array}{l}-41.7 \\
\pm \\
22.4\end{array}$ & $\begin{array}{l}-5.7 \\
\pm \\
3.1\end{array}$ & $\begin{array}{l}-0.23 \\
\pm \\
0.12\end{array}$ & n.a. & n.a. & n.a. & n.a. & n.a. & n.a. \\
\hline $\begin{array}{l}\text { Nam Co } \\
\text { Drainage } \\
\text { Basin }\end{array}$ & $\begin{array}{l}212.5 \\
\pm \\
7.4\end{array}$ & $\begin{array}{l}198.1 \\
\pm \\
5.5\end{array}$ & n.a. & $\begin{array}{l}-14.4 \\
\pm \\
6.5\end{array}$ & $\begin{array}{l}-6.8 \\
\pm \\
3.1\end{array}$ & $\begin{array}{l}-0.27 \\
\pm \\
0.12\end{array}$ & n.a. & n.a. & n.a. & n.a. & n.a. & n.a. \\
\hline $\begin{array}{l}\text { Glaciers } \\
\text { south-east } \\
\text { of the main } \\
\text { ridge }\end{array}$ & $\begin{array}{l}504.8 \\
\pm \\
17.7\end{array}$ & $\begin{array}{l}475.3 \\
\pm \\
13.3\end{array}$ & n.a. & $\begin{array}{l}-29.5 \\
\pm \\
13.3\end{array}$ & $\begin{array}{l}-5.8 \\
\pm \\
2.6\end{array}$ & $\begin{array}{l}-0.23 \\
\pm \\
0.12\end{array}$ & n.a. & n.a. & n.a. & n.a. & n.a. & n.a. \\
\hline $\begin{array}{l}\text { Detailed } \\
\text { study area }\end{array}$ & $\begin{array}{l}207.1 \\
\pm \\
7.2\end{array}$ & $\begin{array}{l}194.5 \\
\pm \\
5.5\end{array}$ & $\begin{array}{l}186.6 \\
\pm \\
5.4\end{array}$ & $\begin{array}{l}-12.6 \\
\pm \\
6.4\end{array}$ & $\begin{array}{l}-6.1 \\
\pm \\
3.1\end{array}$ & $\begin{array}{l}-0.24 \\
\pm \\
0.12\end{array}$ & $\begin{array}{l}-7.8 \\
\pm \\
5.4\end{array}$ & $\begin{array}{l}-4.0 \\
\pm \\
2.8\end{array}$ & $\begin{array}{l}-0.50 \\
\pm \\
0.34\end{array}$ & $\begin{array}{l}-20.5 \\
\pm \\
6.4\end{array}$ & $\begin{array}{l}-9.9 \\
\pm \\
3.1\end{array}$ & $\begin{array}{l}-0.3 \\
\pm \\
0.10\end{array}$ \\
\hline
\end{tabular}
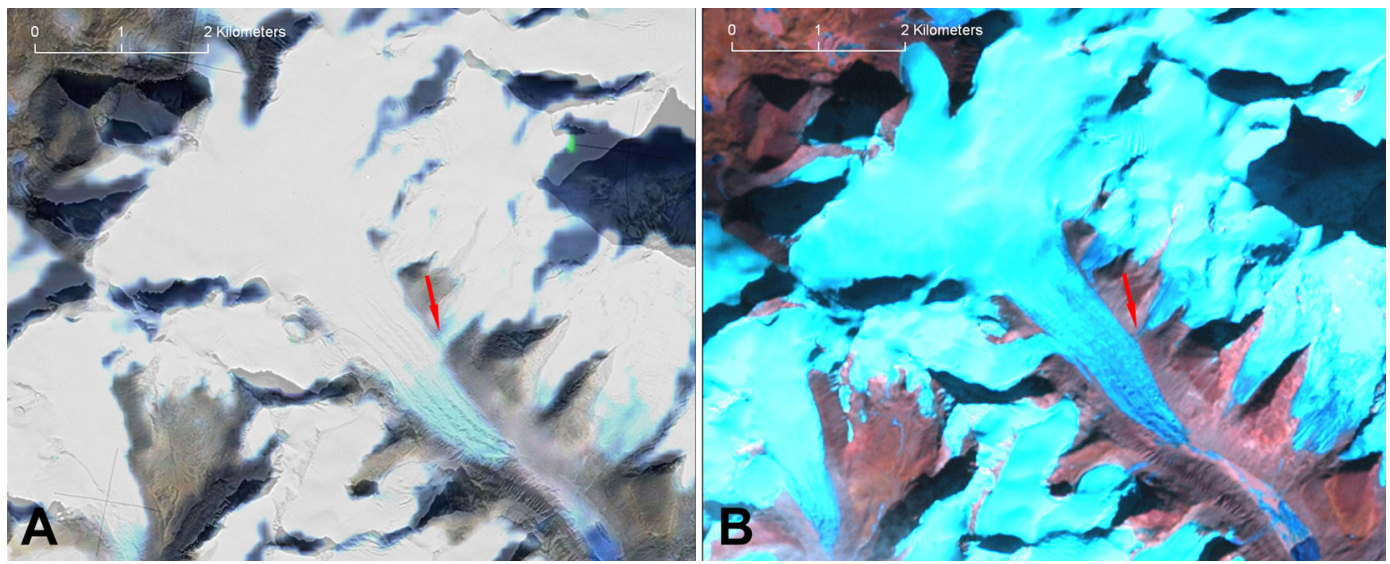

Fig. 10. Panu Glacier 1976 - merge of Landsat MSS and Hexagon (A) and 2001 - Landsat ETM+, 5-4-3-PAN (B). The arrow indicates the separation of one tributary glacier between 1976 and 2001.

for Xibu Glacier $(-1.9 \%)$. There was a slight tendency that retreat rates 1976-1991 were higher than those from 1991 to 2001, but lower than those from 2001 to 2009. One glacier contributing to the main Panu Glacier in 1976 separated from it before 2001 (Fig. 10).

\section{Discussion}

\subsection{Glacier changes}

Spaceborne imagery enabled us setting up a glacier inventory of the western Nyaingentanglha Range, and to trace back changes in glacier extension over a period of more than
40 years. This represents the longest time series over which a change detection of the glacier coverage has been performed for the study region until present. The study found glacier shrinkage and retreat in the western Nyainqentanglha Range between 1976 and 2009 of about $-9.9 \pm 3.1 \%$. The slightly higher glacier shrinkage in Nam Co drainage basin compared to the whole study area and the glaciers east of the main ridge are most likely due to smaller average glacier size in the Nam Co basin. The relatively low shrinkage of the debris-covered glaciers is an indication of the insulation effect of the debris cover. However, their area loss was not significantly lower than of the other glaciers of the study area of similar size. Analysing the glacier hypsography indicated that a rise of the ELA above $5850 \mathrm{~m}$ will cause increased area loss as the 
T. Bolch et al.: A glacier inventory for the western Nyainqentanglha Range and the Nam Co Basin

Table 5. Length and area changes for five selected glaciers. The uncertainty is estimated to be about $3 \%$.

\begin{tabular}{|c|c|c|c|c|c|c|}
\hline $\begin{array}{l}\text { Zhadang } \\
\text { Glac. }\end{array}$ & Area $\left(\mathrm{km}^{2}\right)$ & $\Delta a$ abs. $\left(\mathrm{km}^{2}\right)$ & $\Delta a$ rel. $\left(\mathrm{km}^{2}\right)$ & Rate (\%/yr) & Retreat (m) & Rate $(\mathrm{m} / \mathrm{yr})$ \\
\hline 1976 & 2.75 & & & & & \\
\hline 1991 & 2.56 & -0.19 & $-6.9 \%$ & $-0.46 \%$ & 140 & 9.3 \\
\hline 2001 & 2.48 & -0.08 & $-3.1 \%$ & $-0.31 \%$ & 70 & 7.0 \\
\hline 2005 & 2.41 & -0.07 & $-2.8 \%$ & $-0.71 \%$ & 40 & 10.0 \\
\hline 2009 & 2.36 & -0.05 & $-2.1 \%$ & $-0.52 \%$ & 45 & 11.3 \\
\hline 1976-2001 & & -0.27 & $-9.8 \%$ & $-0.39 \%$ & 210 & 8.4 \\
\hline 2001-2009 & & -0.12 & $-4.8 \%$ & $-0.60 \%$ & 85 & 10.6 \\
\hline 1976-2009 & & -0.39 & $-14.2 \%$ & $-0.43 \%$ & 295 & 8.9 \\
\hline Tangse No. 2 & Area $\left(\mathrm{km}^{2}\right)$ & $\Delta a$ abs. $\left(\mathrm{km}^{2}\right)$ & $\Delta a$ rel. $\left(\mathrm{km}^{2}\right)$ & Rate (\%/yr) & Retreat (m) & Rate $(\mathrm{m} / \mathrm{yr})$ \\
\hline 1976 & 3.13 & & & & & \\
\hline 1991 & 3.02 & -0.11 & $-3.5 \%$ & $-0.23 \%$ & 70 & 4.7 \\
\hline 2001 & 2.96 & -0.06 & $-2.0 \%$ & $-0.20 \%$ & 65 & 6.5 \\
\hline 2005 & 2.95 & -0.01 & $-0.3 \%$ & $-0.08 \%$ & 30 & 7.5 \\
\hline 2009 & 2.89 & -0.06 & $-2.0 \%$ & $-0.51 \%$ & 35 & 8.8 \\
\hline 1976-2001 & & -0.17 & $-5.4 \%$ & $-0.22 \%$ & 135 & 5.4 \\
\hline 2001-2009 & & -0.07 & $-2.4 \%$ & $-0.30 \%$ & 65 & 8.1 \\
\hline 1976-2009 & & -0.24 & $-7.7 \%$ & $-0.23 \%$ & 200 & 6.1 \\
\hline Lalong Glac. & Area $\left(\mathrm{km}^{2}\right)$ & $\Delta a$ abs. $\left(\mathrm{km}^{2}\right)$ & $\Delta a$ rel. $\left(\mathrm{km}^{2}\right)$ & Rate (\%/yr) & Retreat (m) & Rate $(\mathrm{m} / \mathrm{yr})$ \\
\hline 1976 & 10.5 & & & & & \\
\hline 1984 & 10.43 & -0.07 & $-0.7 \%$ & $-0.08 \%$ & 170 & 21.3 \\
\hline 2001 & 10.29 & -0.14 & $-1.3 \%$ & $-0.08 \%$ & 190 & 11.9 \\
\hline 2005 & 10.25 & -0.04 & $-0.4 \%$ & $-0.10 \%$ & 60 & 15.0 \\
\hline 2009 & 10.21 & -0.04 & $-0.4 \%$ & $-0.10 \%$ & 30 & 7.5 \\
\hline 1976-2001 & & -0.21 & $-2.0 \%$ & $-0.08 \%$ & 360 & 14.4 \\
\hline 2001-2009 & & -0.05 & $-0.5 \%$ & $-0.06 \%$ & 90 & 11.3 \\
\hline 1976-2009 & & -0.26 & $-2.5 \%$ & $-0.08 \%$ & 450 & 13.6 \\
\hline Xibu Glac. & Area $\left(\mathrm{km}^{2}\right)$ & $\Delta a$ abs. $\left(\mathrm{km}^{2}\right)$ & $\Delta a$ rel. $\left(\mathrm{km}^{2}\right)$ & Rate (\%/yr) & Retreat (m) & Rate $(\mathrm{m} / \mathrm{yr})$ \\
\hline 1976 & 23.55 & & & & & \\
\hline 1984 & 23.43 & -0.12 & $-0.5 \%$ & $-0.06 \%$ & 120 & 15.0 \\
\hline 1991 & 23.39 & -0.04 & $-0.2 \%$ & $-0.02 \%$ & 50 & 7.1 \\
\hline 2001 & 23.35 & -0.04 & $-0.2 \%$ & $-0.02 \%$ & 60 & 6.0 \\
\hline 2005 & 23.04 & -0.5 & $-2.1 \%$ & $-0.33 \%$ & 50 & 12.5 \\
\hline 2009 & 22.90 & -0.14 & $-0.6 \%$ & $-0.15 \%$ & 50 & 12.5 \\
\hline 1976-2001 & & -0.2 & $-0.9 \%$ & $-0.03 \%$ & 230 & 9.2 \\
\hline 2001-2009 & & -0.36 & $-1.5 \%$ & $-0.24 \%$ & 100 & 12.5 \\
\hline 1976-2009 & & -0.44 & $-1.9 \%$ & $-0.07 \%$ & 330 & 10.0 \\
\hline Panu Glac. & Area $\left(\mathrm{km}^{2}\right)$ & $\Delta a$ abs. $\left(\mathrm{km}^{2}\right)$ & $\Delta a$ rel. $\left(\mathrm{km}^{2}\right)$ & Rate (\%/yr) & Retreat (m) & Rate $(\mathrm{m} / \mathrm{yr})$ \\
\hline 1976 & 13.18 & & & & & \\
\hline 1984 & 13.16 & -0.02 & $-0.2 \%$ & $-0.02 \%$ & 100 & 12.5 \\
\hline 1991 & 13.01 & -0.15 & $-1.1 \%$ & $-0.16 \%$ & 80 & 11.4 \\
\hline 2001 & 12.88 & -0.13 & $-1.0 \%$ & $-0.06 \%$ & 190 & 19.0 \\
\hline 2005 & 12.86 & -0.02 & $-0.2 \%$ & $-0.04 \%$ & 70 & 17.5 \\
\hline 2009 & 12.78 & -0.08 & $-0.6 \%$ & $-0.16 \%$ & 30 & 7.5 \\
\hline 1976-2001 & & -0.3 & $-2.3 \%$ & $-0.09 \%$ & 370 & 14.8 \\
\hline 2001-2009 & & -0.1 & $-0.8 \%$ & $-0.10 \%$ & 100 & 12.5 \\
\hline 1976-2009 & & -0.38 & $-2.9 \%$ & $-0.09 \%$ & 470 & 14.2 \\
\hline
\end{tabular}


largest portion of glacier coverage is in the range of 5750 $5850 \mathrm{~m}$.

Our results are in tendency in agreement with previous studies. Field measurements and analysis of topographic maps carried out for Gurenhekou Glacier, located in the southern part of the range, showed an increased termini retreat rate after 1970 (Pu et al., 2006). Analysis of five glaciers around Mt. Nyainqentanglha suggests that glacier termini have been retreating around $-10 \mathrm{~m} \mathrm{a}^{-1}$ from 1970 to 2007, with a significantly higher rate $(\sim-39 \mathrm{~m} / \mathrm{a})$ for the debriscovered Xibu Glacier (Kang et al., 2007a). Our results for length changes reveal similar values to the previous studies but significantly lower rates for Xibu Glacier. Kang et al. (2007a) compared GPS data obtained in the field with the position of the terminus as shown in the Chinese topographic map (scale 1:100 000). Hence, taking into account that usually the debris cover would reduce the retreat of the tongue, it is likely that this comparably high value can be attributed to wrong glacier delineation in the map.

Previous glacier change studies for the Nam Co basin showed a glacier area decrease by $-15.4 \%$ from 1970 to 2000 (Yao et al., 2007; Wu and Zhu, 2008), while Frauenfelder and Kääb (2009) found an area decrease of -20\% for the SE side of the Nyainqentanglha Range in a similar period. This study, however, results in lower values for glacier area changes to previous studies for a similar time period. One explanation for the differences could be that Yao et al. (2007) and Wu and Zhu (2008) used mainly data from the Chinese Glacier Inventory (CGI) (Li, 2003). This inventory also used the Chinese topographic maps, which are based on aerial images acquired in the early 1970s, and were published in the 1970s and 1980s. Main reasons for the deviations to our data are probably different interpretation of debris-cover and seasonal snow on the utilized aerial images, which is known to be one of the major problems of maps (Bhambri and Bolch, 2009), as well as glacier shrinkage since the 1970s. Frauenfelder and Kääb (2009) used Corona imagery to validate the data from the CGI and found errors in georeferencing, which can be confirmed by this study. They omitted glaciers with obvious errors from the CGI for their change analysis but did not correct the remaining glaciers. Hence, the reason of the difference to our data is likely due to the inaccurate 1970s data. The quality of the CGI and Chinese topographic maps can hardly be evaluated if the original imagery is not available. Declassified imagery from the 1970s therefore provides a good opportunity for validation and to further improve the data from the CGI. Hexagon $\mathrm{KH}-$ 9 data is superior to Corona due to less image distortion and larger footprints. Slight differences of some automated derived ice divides to the former Chinese Glacier Inventory led to different length and absolute areas for some glaciers, e.g. Zhadang Glacier (Chen et al., 2009). The terrain of the ice divide is almost flat in these cases. Further investigations, e.g. based on higher resolution DEMs, are required to identify the correct surface divide. However, the automated method is reproducible and this uncertainty does not affect the results of our study as we kept the ice divides constant for our analysis.

Our results indicate that glacier changes in the western Nyainqentanglha Range are similar to the average changes for whole China ( $-5.5 \%$ since the $1960 \mathrm{~s}$; Li et al., 2008). The recent acceleration of the retreat can also be found in most parts of the TiP (Kang et al., 2010). Values might be slightly but not significantly lower in other areas of central and western Tibet, e.g., the Geladanong Mountains about $500 \mathrm{~km}$ to the north of the study area (Ye et al., 2006; $-4.8 \%$ between 1969 and 2002). Glacier shrinkage in Tibet south of the study area seems to be higher: Zhou et al., 2009 found a $\sim-5 \%$ decrease between 1990 and 2005 in Nianchu River basin. However, these data can only show tendencies as different time periods and size classes are compared.

\subsection{Climatic considerations}

The significantly larger ice cover east of the main ridge of the Nyainqentanglha Range wind-ward to the summer monsoon is an indication that precipitation is higher in this region than leeward of the main ridge. However, the values of the glacier change rates are comparable, which indicates similar dominant influence of long-term regional climate variability in the study area. The reported temperature increase since the 1950 s varies between $0.3 \mathrm{~K}$ per decade for the station Lhasa, which was shown to be representative for a larger region (Liu and Chen, 2000). A recent study using similar data also revealed a general warming trend, especially in winter months (You et al., 2010). The trend coefficient for the station Lhasa was $0.44 \mathrm{~K} / 10 \mathrm{a}$ (winter months, dry season) and $0.23 \mathrm{~K} / 10 \mathrm{a}$ (summer months, wet season) for 1955-2005 (Caidong and Sortenberg, 2010). The stations adjacent to the Nyainqentanglha Range and Amdo station had similar tendencies (Chen et al., 2009; Liu et al., 2009). Liu and Chen (2000) assumed a higher temperature increase in higher elevations. In contrast, Qin et al. (2009) showed, by using remote sensing data, that this altitudinal dependency may not be that pronounced, and levels out at elevations higher than $5000 \mathrm{~m}$. The changes in air temperature were accompanied by an increase of precipitation due to variations in monsoonal activity. Liu et al. (2009) analysed data of the station Amdo, and recorded multi-year oscillations in precipitation from 1965 to the mid1990s, followed by a trend to increasing precipitation since 1995. The July precipitation even slightly decreased until the mid 1990s (Thomas and Chen, 2002). Annual precipitation in the last decade was $50.6 \mathrm{~mm}$ (about 12\%) above the average annual mean during the period 1965-1994. The same tendency was observed by Shi et al. (2006), Kang et al. (2007b), and Chen et al. (2009) for the stations adjacent to our study region. Pan evaporation showed stable or slightly increasing values until the mid 1990s (Thomas and Chen, 2002) and a decrease thereafter (Liu et al., 2010). 
Linking the presented glacier area and length changes to the above summarized climate variations is not straightforward, mainly because (a) the glacier changes are only indirect signals and depend especially on glacier response times, (b) the availability of the climate data in the study area and especially at the altitude range of the glacier occurrence is very scarce.

The present knowledge on the response of polythermal, summer-accumulation type glaciers to climate changes at different time scales is still limited. Glacier size, shape, motion, and the local topography also influence the glacier response. On average, the response time can possibly be several decades (Naito et al., 2001). The summer-accumulationtype glaciers are more vulnerable to temperature increase than winter accumulation type glaciers (Fujita and Ageta, 2000; Fujita, 2008). Hence, it can be assumed that the observed warming in the wet season is the major driver for glacier changes. This is also confirmed by a recent modelling study on Xibu Glacier. The change in summer temperature was found to be more important than precipitation changes or the changes in winter (dry season) temperature even although the increase of winter temperature was found to be significantly higher than in summer (Caidong and Sortenberg, 2010). Changes in the summer temperature affect both the glacier melt and the snow line altitude. The latter has an important effect on the melt due to albedo changes.

Precipitation seasonality also plays an important role. For example, the early onset of wet season may suppress glacier melt during summer, and can lead into positive mass balance values (Kang et al., 2009). The presented glacier shrinkage may reflect the time prior to 1990 with slightly decreasing summer precipitation, but slightly increasing evaporation and temperature when considering the response time of the glacier. The recent trend since the mid 1990s with a stronger temperature increase but also slightly increasing precipitation and evaporation may not yet be reflected in our data. Taking the importance of the temperature variations for the glacier mass balance into account, it is likely that glaciers will continue to shrink even though some positive mass balance years occur in between. However, recent mass balance measurements on Zhadang Glacier are mostly negative (Kang et al., 2009). So far, we are not able to quantify the importance of the specific climate elements to the glacier changes since availability of climate data in the study area is insufficient. Especially the influence of solar radiation and sublimation needs further investigation. Ongoing investigations (e.g. direct mass balance measurements, meteorological energy balance measurements on Zhadang Glacier and at Nam Co station, acquisition of gridded climate data, and geodetic estimates of glacier mass changes by DEM differencing) will continuously improve the data base in the near future, and will help to adjust existing glacier models to the specific situation in the study area. The availability of the presented glacier outlines are of high importance for model validation and hence also for the investigation of climate change. Lake level variations of Nam Co are another source for model validation since glacier run-off is influenced by glacier variability (Yao et al., 2007; Wu and Zhu, 2008; Liu et al., 2010).

\section{Conclusions}

This study demonstrated the scientific value of detailed multi-temporal remote sensing analyses of glacier changes for regions that do not have sufficient observational data records. Our approach and the availability of precise orthorectified Landsat scenes allow repeated monitoring in the study area without costs for data every three to five years, if retreat rates remain unchanged. Future efforts to continue this time series will be minor as glacier drainage divides are already generated. Next steps will involve automated mapping of the debris-covered parts of glaciers. The availability of different optical satellite imagery from earlier years, especially the low cost Hexagon KH-9 from the 1970s and Landsat TM scenes from the 1980s and 1990s is of high value for glacier investigations. This allows evaluating existing data or glacier outlines from older topographic maps and deriving multi-temporal glacier inventories dating back several decades. The main drawback for some regions might be the unavailability of suitable scenes. However, in our study area characterised by continental climate little snow cover and clouds throughout the year facilitates the generation of multi-temporal glacier inventories. The Chinese Glacier Inventory from the 1970 is a valuable source of information but the data contains inaccuracies and geolocation errors. The use of different satellite data revealed a continuous glacier shrinkage of about $-9.9 \pm 3.1 \%$ from 1976 until 2009. These values are lower than previously published results, which can be mainly attributed to the uncertainties of glacier delineations based on the Chinese topographic maps. The five glaciers investigated in detail showed an average retreat of about $-10 \mathrm{~m} / \mathrm{a}$ from 1976 until 2009. No glaciers advanced in the investigated periods. The larger ice cover of the south-eastern side of the Nyainqentanglha Range reflects the location windward to the summer monsoon. Short-term variations in the glacier mass balance were also driven by monsoonal variations. The main cause of long-term glacier wastage, however, was likely the increase in air temperature during the wet season. However, the complex glacier-climate interactions need to be further investigated.

Acknowledgements. The work is supported by the German Research Foundation (Deutsche Forschungsgemeinschaft, DFG) within the Tibetan Plateau (TiP) Priority Programme under the codes BU 949/20-1, SCHE 750/4-1, and SCHN 680/3-1. The authors are grateful to the German Aero Space Center (Deutsches Zentrum für Luft- und Raumfahrt, DLR) for providing the Metric Camera data at no cost. We thank Volker Hochschild, Jan Kropacek (both Universität Tübingen, Germany), Wolfgang Flügel, and Peter Krause (both Universität Jena, Germany) for the cooperation. 
The valuable comments of Mauri Pelto, Adina Racoviteanu, an anonymous reviewer, and the scientific editor Andreas Kääb considerably helped to improve the quality of this contribution.

Edited by: A. Kääb

\section{References}

Ageta, Y. and Fujita, K.: Characteristics of mass balance of summer-accumulation type glaciers in the Himalayas and Tibetan Plateau, Z. Gletscherkd. Glazialgeol., 32, 61-65, 1996.

Berry, P. A. M., Garlick, J. D., and Smith, R. G.: Near-global validation of the SRTM DEM using satellite radar altimetry, Remote Sens. Environ., 106, 17-27, 2007.

Bhambri, R. and Bolch, T.: Glacier Mapping: A Review with special reference to the Indian Himalayas, Prog. Phys. Geog., 33(5), 672-704, 2009.

Böhner, J.: General climatic controls and topoclimatic variations of Central and High Asia, Boreas, 35(2), 279-295, 2006.

Bolch, T., Buchroithner, M. F., Pieczonka, T., and Kunert, A.: Planimetric and volumetric Glacier changes in Khumbu Himalaya since 1962 using Corona, Landsat TM and ASTER data, J. Glaciol., 54(187), 592-600, 2008.

Bolch, T. and Kamp, U.: Glacier Mapping in High Mountains using DEMs, Landsat and ASTER Data, Grazer Schriften der Geographie und Raumforschung, 41, Proc. 8th Int. Symp. on High Mountain Remote Sensing Cartography, 20-27 March 2005, La Paz, Bolivia, 13-24, 2006.

Bolch, T., Menounos, B., and Wheate, R. D.: Landsat-based inventory of glaciers in western Canada, 1985-2005, Remote Sens. Environ., 114(1), 127-137, 2010.

Braithwaite, R. J. and Raper, S. C. B.: Estimating equilibrium-line altitude (ELA) from glacier inventory data, A. Glaciol., 50, 127132, 2010.

Caidong, C. and Sorteberg, A.: Modelled mass balance of Xibu glacier, Tibetan Plateau: sensitivity to climate change, J. Glaciol., 56(196), 235-248, 2010.

Chen, F., Kang, S., Zhang, J., and You, Q.: Glaciers and lake change in response to climate change in the Nam Co Basin, Tibet, (in Chinese with English abstract), J. Mt. Sci., 27(6), 641-647, 2009.

Ding, Y., Liu, S., Li, J., and Shangguan, D.: The retreat of glaciers in response to recent climate warming in western China, Ann. Glaciol., 43, 97-105, 2006.

Falorni, G., Teles, V., Vivoni, E. R., Bras, R. L., and Amartunga, K. S.: Analysis and characterization of the vertical accuracy of digital elevation models fro $m$ the Shuttle Radar Topography Mission, J. Geophys. Res., 110, F02005, doi:10.1029/2003JF000113, 2005.

Frauenfeld, O. W., Zhang, T., and Serreze, M. C.: Climate change and variability using European Centre for MediumRange Weather Forecasts reanalysis (ERA-40) temperatures on the Tibetian Plateau, J. Geophys. Res., 110, D02101, doi:10.1029/2004JD005230, 2005.

Frauenfelder, R. and Kääb, A.: Glacier mapping from multitemporal optical remote sensing data within the Brahmaputra river basin, Proc. 33rd int. Symposium on Remote Sensing of Environment, 4-8 May 2009, Stresa, Italy, Tucson, Arizona, International Center of Remote Sensing of Environment, Paper 299, 4 pp., 2009.
Fujita, K.: Influence of precipitation seasonality on glacier mass balance and its sensitivity to climate change, Ann. Glaciol., 48, 88-92, 2008.

Fujita, K. and Ageta, Y.: Effect of summer accumulation on glacier mass balance on the Tibetan Plateau revealed by mass-balance model, J. Glaciol., 46(153), 244-252, 2000.

Fujita, K., Ohta, T., and Ageta, Y.: Characteristics and climatic sensitivities of runoff from a cold-type glacier on the Tibetan Plateau, Hydrol. Process., 21, 282-289, 2007.

Fujita, K., Seko, K., Ageta, Y., Pu, J., and Yao, T.: Superimposed ice in glacier mass balance on the Tibetan Plateau, J. Glaciol., 42(142), 454-460, 1996.

Granshaw, F. D. and Fountain, A. G.: Glacier change (1958-1998) in the North Cascades National Park Complex, Washington, USA, J. Glaciol., 52(177), 251-256, 2006.

Huang, M.: On the temperature distribution of glaciers in China, J. Glaciol., 36(123), 210-216, 1990.

Immerzeel, W., van Beek, L. P., and Bierkens, M. F.: Climate change will affect the Asian water towers: Science, 328, 1382$1385,2010$.

Kääb, A.: Monitoring high-mountain terrain deformation from repeated air- and spaceborne opitcal data: examples using digital aerial imagery and ASTER data, J. Photogr. Remote Sens., 57, 39-52, 2001.

Kamp, U., Bolch, T., and Olsenholler, J.: Geomorphometry of Cerro Sillajhuay, Chile/Bolivia: comparison of DEMs derived from ASTER remote sensing data and contour maps, Geocarto International, 20(1), 23-34, 2005.

Kang, S., Chen, F., Ye, Q., Jing, Z., Qin, D., and Ren, J.: Glacier retreating dramatically on Mt. Nyainqêntanglha during the last 40 years. (In Chinese with English summary), J. Glaciol. Geocryol., 29(6), 869-873, 2007a.

Kang, S., Qin, D., Ren, J., Zhang, Y., Kaspari, S., Mayewski, P. A., and Hou, S.: Annual accumulation in the Mt. Nyainqentanglha ice core, southern Tibetan plateau, China: Relationships to atmospheric circulation over Asia, Arct. Antarct. Alp. Res., 39, 663-670, 2007b.

Kang, S., Chen, F., Gao, T., Zhang, Y., Yang, W., Yu, W., and Yao, T.: Early onset of rainy season suppresses glacier melt: a case study on Zhadang glacier, Tibetan Plateau, J. Glaciol., 55(192), 755-758, 2009.

Kang, S., Wei, X., You, Q., Flügel, W., Pepin, N., and Yao, T.: Review of climate and cryospheric change in the Tibetan Plateau, Environ. Res. Lett., 5, 015101, doi:10.1088/17489326/5/1/015101, 2010.

Konecny, G., Reynolds, M., and Schroeder, M.: Mapping from Space: The Metric Camera experiment, Science, 225(4658), 167-169, 1984.

Li, X.: GLIMS Glacier Database, Boulder, CO, National Snow and Ice Data Center/World Data Center for Glaciology, Digital Media, 2003.

Li, X., Cheng, G., Jin, H., Kang, E., Che, T., Jin, R., Wu, L., Nan, Z., Wang, J., and Shen, Y.: Cryospheric change in China, Global Planet. Change, 62(3-4), 210-218, 2008.

Liu, J., Wang, S., Yu, S., Yang, D., and Zhang, L.: Climate warming and growth of high-elevation inland lakes on the Tibetan Plateau, Global Planet. Change, 67, 209-217, 2009.

Liu, J., Kang, S., Gong, T., and Lu, A.: Growth of a high-elevation large inland lake, associated with climate change and permafrost 
degradation in Tibet, Hydrol. Earth Syst. Sci., 14, 481-489, doi:10.5194/hess-14-481-2010, 2010.

Liu, X. and Chen, B.: Climatic warming in the Tibetan Plateau during recent decades, Int. J. Climatol., 20(14), 1729-1742, 2000.

Ma, D., Tu, J., Cui, P., and Lu, R.: Approach to Mountain Hazards in Tibet, China, J. Mt. Sci., 1(2), 143-154, 2004.

Miehe, G., Winiger, M., Böhner, J., and Zhang, Y.: The climatic diagram map of High Asia, Purpose and concepts, Erdkunde, 55, 94-97, 2001.

Narama, C., Kääb, A., Duishonakunov, M., and Abdrakhmatov, K.: Spatial variability of recent glacier area changes in the Tien Shan Mountains, Central Asia, using Corona (1970), Landsat (2000), and ALOS (2007) satellite data, Global Planet. Change, 71(1-2), 42-54, 2010.

Naito, N., Ageta, Y., Nakawo, M., and Waddington, E. D.: Response sensitivities of a summer-accumulation type glacier to climate changes indicated with a glacier fluctuation model, B. Glaciol. Res., 18, 1-8, 2001.

Paul, F. R., Barry, R. G., Cogley, J. G., Frey, H., Haeberli, W., Ohmura, A., Ommanney, C. S. L., Raup, B., Rivera, A., and Zemp, M.: Recommendations for the compilation of glacier inventory data from digital sources, Ann. Glaciol., 50(53), 119126, 2009.

Paul, F. A., Kääb, A., Maisch, M., Kellenberger, T., and Haeberli, W.: The new remote sensing derived Swiss Glacier Inventory: I. Methods, Ann. Glaciol., 34, 355-361, 2002.

$\mathrm{Pu}$, J., Yao, T., and Tian, L.: Change of the Gurenhekou Glacier in Yangbajain Area, Nyainqêntanglha Range, J. Glaciol. Geocryol., 28(6), 861-864, 2006.

Qin, J., Yang, K., Liang, S., and Guo, X.: The altitudinal dependence of recent rapid warming over the Tibetan Plateau, Climatic Change, 97(1-2), 321-327, 2009.

Racoviteanu, A. E., Paul, F., Raup, B., Khalsa, S. J. S., and Armstrong, R.: Challenges and recommendations in mapping of glacier parameters from space: results of the 2008 Global Land Ice Measurements from Space (GLIMS) workshop, Boulder, Colorado, USA, Ann. Glaciol., 50, 53-69, 2009.

Sato, T.: Spatial and temporal variations of frozen ground and snow cover in the eastern part of the Tibetan Plateau, J. Meteorol. Soc. Jpn., 79(1B), 519-534, 2001.

Schiefer, E., Menounos, B., and Wheate, R. D.: An inventory and morphometric analysis of British Columbia glaciers, Canada, J. Glaciol., 54(186), 551-560, 2008.

Schütt, B., Berking, J., Frechen, M., and Yi, C.: Late Pleistocene Lake Level Fluctuations of the Nam Co, Tibetan Plateau, China, Z. Geomorphol., Supplementary Issues, 52(2), 57-75, 2008.

Shi, Y., Hsieh, T., Chen, P., and Li, C. Distribution, features and variation of glaciers in China, IAHS Publ., 126, 111-116, 1980.

Shi, Y. and Liu, S.: Estimation on the response of glaciers in China to the global warming in the 21st century, Chinese Sci. Bull., 45(7), 668-672, 2000.
Shi, Y., Liu, S., Shangguan, D., Li, D., and Ye, B.: Peculiar phenomena regarding climatic and glacial variations on the Tibetan Plateau, Ann. Glaciol., 43, 106-110, 2006.

Surazakov, A. B. and Aizen, V. B.: Positional accuracy evaluation of declassified Hexagon KH-9 mapping camera imagery, Photogramm. Eng. Rem. S., 76(5), 603-608, 2010.

Thomas, A. and Chen, S.: Landwirtschaft und klimatische Trends im Yarlong Tsangpo-Tal, Tibet, Erdkunde, 56(4), 351-384, 2002.

Toutin, T.: ASTER DEMs for geomatic and geoscientific applications: a review, Int. J. Remote Sens., 29(7), 1855-1875, 2008.

Tucker, C., Grant, D., and Dykstra, J.: NASA's global orthorectified Landsat data set, Photogramm. Eng. Remote Sens., 70(3), 313322, 2004.

Wu, Y. and Zhu, L.: The response of lake-glacier variations to climate change in Nam Co Catchment, central Tibetan Plateau, during 1970-2000, J. Geogr. Sci., 18(2), 177-189, 2008.

Xiao, C., Liu, S., Zhao, L., Wu, Q., Li, P., Liu, C., Zhang, Q., Ding, Y., Yao, T., Li, Z., and Pu, J.: Observed changes of cryosphere in China over the second half of the 20th century: an overview, Ann. Glaciol., 46, 382-390, 2007.

Yao, T.: Map of Glaciers and Lakes on the Tibetan Plateau and Adjoining Regions 1:2000 000, Xian Cartographic Publishing House, 2008.

Yao, T., Pu, J., Lu, A., Wang, Y., and Yu, W.: Recent glacial retreat and its impact on hydrological processes on the Tibetan Plateau, China, and surrounding regions, Arct. Antarct. Alp. Res., 39(4), 642-650, 2007.

Ye, Q., Kang, S., Chen, F., and Wang, J.: Monitoring glacier variations on Geladandong Mountian, central Tibetan Plateau, from 1969 to 2002 using remote-sensing and GIS technologies, J. Glaciol., 52(179), 537-545, 2006.

You, Q., Kang, S., Tian, K., Liu, J., Li, C., and Zhang, Q.: Preliminary analysis on climatic features at Mt. Nyainqentanglha, Tibetan Plateau, (in Chinese with English abstract), J. Mt. Sci., 25(4), 497-504, 2007.

You, Q., Kang, S., Aguilar, E., Flügel, W., and Yan, Y.: Relationship between temperature trend magnitude, elevation and mean temperature in the Tibetan Plateau from homogenized surface stations and reanalysis data, Global Planet. Change, 71, 124-133, 2010.

Zhang, Y., Kang, S., and Li, M.: Climatic features at Nam Co station, Tibetan Plateau, Annual Report of Nam Co Station for Multisphere observation and Research, 3, 1-8, 2008.

Zhao, L., Ping, C., Yang, D., Cheng, G., Ding, Y., and Liu, S.: Changes of climate and seasonally frozen ground over the past 30 years in Qinghai-Xizang (Tibetan) Plateau, China, Global Planet. Change, 43, 19-31, 2004.

Zhou, C., Yang, W., Wu, L., and Liu, S.: Glacier changes from a new inventory, Nianchu river basin, Tibetan Plateau, Ann. Glaciol., 50(53), 87-92, 2009. 